doing", deciding instead to go to trial. Given the penchant of US juries to go after big corporations (especially those accused of causing environmental damage), Monsanto took a big risk that paid off only last week, when an appeals court threw out a jury verdict that the company should pay more than $\$ 16$ million in punitive damages.

The original trial, known as Kemner (for one of the plaintiffs) $v$. Monsanto, lasted for 44 months, setting a record as the longest jury trial in US history. More than 200 witnesses testified. More than 6000 exhibits were offered in evidence. When it was all finally over, the jurors concluded that there were no scientific data to support the plaintiffs' claims that they had been injured by dioxin. But the same jurors did not let science or commonsense cloud their judgement when they slapped the $\$ 16$ million penalty on Monsanto.

Last week, the Missouri appellate court, evidently better endowed with commonsense, put things right when it ruled that the jury could not have it both ways. If there is no evidence of injury, there can be no justification for punitive damages. The wonder is that the case got that far in the first place. That the US tort system has run amok, as this case illustrates, is nothing new. But the depth of scientific ignorance and hostility towards scientifically based industry revealed by the jurors' action is frightening, leaving the suspicion that they might actually have believed the claims of dioxin injury even in the absence of data. Monsanto could probably have saved itself millions of dollars by settling case out of court, but would then have perpetuated the idea that any level of exposure to a toxic chemical, however small, is hazardous to people's health.

\section{Policy by stealth}

Science has become a British election issue, but as yet in an unreconstructed fashion.

IF proof were needed that Britain is in the throes of an undated general election campaign, the manner in which the Conservative or government party announced its policy for science and research last week provides it. Weeks ago, the Labour Party had booked a lecture hall at the Royal Institution for 4 June, and had announced that Mr Neil Kinnock, its leader (called "Leader") would introduce Labour's much leaked science policy then. So, the Conservatives seem to have calculated, would it not be a splendid wheeze to announce their own policy for science the previous evening? That, in the event, is what happened, but with such haste that many (this journal included) did not learn what was afoot in time, and thus reported only the contents of Labour's document (see Nature 351, 512; 13 June 1991). What follows may make amends (but only partially).

What the Conservative Party says of its record over twelve years is not in itself objectionable: much of it is also factually true. At the school level, the government has indeed made science a part of the national curriculum. In basic research, there has indeed been an increase of 22 per cent (allowing for inflation) in funds spent through the five research councils, showing that Mrs Margaret Thatcher's promise to "protect" the science budget has literally been kept. And it is also true that "our scientists continue to excel" (witness Nobel Prizes, bibliometric indices and such innovations as DNA fingerprinting, typing of the virus responsible for seal kills in 1987 and 1988 and the discovery of the Antarctic ozone hole).

True, there is a fly in the ointment - government spending on civil science has fallen as a proportion of gross domestic product over the past decade, but (the Conservatives say) that reflects both an increase of GDP greater than 22 per cent and the government's decision (half-way through the decade) not to support "near-market research". So why is the government's record so widely (although not generally) pilloried?

The polemical part of the Conservatives' anticipatory response to Labour rests on the charge that the Labour Party stands for massive public spending and the central direction of affairs. (The wider political argument in the general election in the next twelve months may be decided by the British electorate's view of whether Labour has, as it claims, given up these old hankerings.) Curiously, the Conservative Party overlooks its own proclivities for telling others, especially academics and researchers, how they should conduct themselves.

In the history of British research policy, the 1980s stand out as the decade in which research councils were given specific marching orders (on matters such as support for information technology), budgets were changed to accommodate government prejudices (for the Antarctic, against social research), when research councils were coerced into thinking up schemes for collaborative research with industry more quickly than they could think them through and when the whim for directed administrative change (in universities as well as research establishments) led to the waste of funds, the needless (and expensive) retirement of useful people and the distraction and demoralization of many able people. The 1980s in Britain are a vivid proof that an intellectual enterprise can be ruined without starving it of funds, but simply by kicking it in the teeth often enough.

Has this lesson now been learned? The Conservatives do not directly acknowledge that the government's predecessor was outrageously a busybody in dealing with the British research community, but there is a hopeful sign in the subtitle of the Conservative science policy - the phrase "the cultural revolution". The text, among others things, makes the valid point that innovation flourishes only when the wider economic climate is welcoming, at least implying that if it were reelected, it would not go about telling researchers that it is their "bounden duty" (one of Mrs Margaret Thatcher's little phrases) to make the country prosperous.

Instead, the Conservatives say they want to bring about in British industry "a revolution in cultural attitudes towards innovation". High time. The irony is that their government is struggling to right an economy in which last decade's entrepreneurs are being forced to the wall in great numbers. The memory of this will not be quickly exorcised even if prosperity is restored before the general election. 